\title{
Parents' Socio-Economic Background as a Predictor of Students’ Performance in E-Learning Education
}

\author{
Smart Odunayo, Olugbeko ${ }^{1}$, Emmanuel Nkoro, Asagha $^{2}$ and Patrick Aliu Akinmusire ${ }^{1}$ \\ ${ }^{1}$ School of Education, Adeyemi College of Education, Ondo, Nigeria \\ ${ }^{2}$ School of Science, Federal College of Education, Obudu, Nigeria. \\ smartruvic@yahoo.com, aenkoro38@gmail.com
}

\begin{abstract}
Parents give lives to their children; they biologically determine the quality of intelligence of their children even at birth. The socio-economic background of the parents exposes the children to after birth factors that help in nourishing or malnourishing the children. The type of education a child gets, how he gets it, where he gets it, why he gets it, when he gets are all fuelled by the parents' socio economic factors. This paper examines the emergence of elearning in Nigeria, the factors associated with its operations, its role in giving the desired level of education to the people and how socio economic background of the parents have affected the performance of students in e-learning education. The study made use of 230 students in e-learning classes, the performances of the randomly selected students were examined vis a vis their parental socio-economic background. The data collected were analyzed using ANOVA at (0.05 alpha level) and the result revealed a significant effect of parents' socio-economic background on students' performance in elearning education. The study recommends among other things a reorientation of parents on their roles in determining the future of their children.
\end{abstract}

Index Terms - e-learning, socio-economic, performance, education, learning

\section{Introduction}

Education is a principal measure of bringing about changes in the lives of individuals and also helps to direct the society in which they live. Education, according to [3] is regarded as a tool for development. E-learning which is the use of Information, Communication and Technology (ICT) to facilitate and fast track learning has become a veritable tool to make education affordable, accessible and effective. The socio-economic background of the students determines the extent to which they benefit from e-learning education; this is because this form of education involves major expenses, exposure and skills on the part of the learner. Thus, the background of the learner becomes a veritable factor that predicts the learners' performance in e-learning education.

\section{What is E-Learning Education?}

E-Learning is a very broad term for electronic method of learning which is closely associated with internet-based learning in general. Distance education has made e-learning more pouplar as it has become a veritable way to bridge the distance between the teacher and the learner, between the writer and the speaker [7]. E-Learning has become synonymous with the latest approach to providing high quality educational offerings. E-Learning according to [9] is defined as technology-supported learning and the delivery of content via all electronic media. E-Learning places greater emphasis on interaction and communication. Interaction with the instructor and with other students which may occur through internet-channels, videoconferencing or teleconferencing, in asynchronous (email or bulletin board) sessions or synchronous (e. g., chat room, whiteboard, application sharing) sessions.

\section{Basic Socio-Economic Factors}

According to [2] one important obvious barrier to students' academic achievement is the socio-economic backgrounds of the students. The socio-economic status is associated with a very complex number of variables. Environment is not a simple or one dimensional thing and socio-economic status is related to the family characteristics, a family size increases in Nigeria among the lowly educated. Poor parental care with gross deprivation of social and economic needs of a child, usually yield poor academic performance of the child. In the recent study of the use of learning technology in Nigeria, [6] found out that a vast majority of students' homes were found to lack computers and internet links. Thus students that were not exposed to learning technology at home will have some problems during e-learning education. According to [1], occupation is a useful index of social class position because it determines so many aspects of a person's social life such as family background, educational qualifications, speech and manners etc. It was [5] who opined that parents with professional and high managerial post have high income level and hence have the financial capacity to expose their children to learning technology.. It is hypothesized that the parents of socio-economic upper class have more positive attitude towards their children schooling and have expectation and standard for the children.

\section{E-Learning Education and Students' Socio-Economic Background}

[10] found that lack of required skills, lack of access to ICT, and the location of the learner are critical factors that pose as barriers to learning for students from lower socioeconomic background. [9] argue that the advent of blended learning and e-learning innovations has ostracised, marginalised or ignored those who cannot afford, or who are unable to access, the latest hardware and software for the purpose of learning. Those without the ability to access these necessities are having problem in accomplishing their educational tasks thus being indirectly marginalised by the 
universities, which is harmful to principles of universal access to education. There is also the problem of generalisation which makes the designer of e-learning to assume that all students have access to computers equipped with the latest soundcards, media players and broadband connections. [2] noted that Nigerians are desirious of having personal computers, particularly with respect to laptops but evidence about the disadvantaged minority on the wrong side of the digital divide who cannot afford their own personal computer or laptop is high

In Nigeria, the cost of purchasing computers of all kinds, modems and subscribing to them has risen above the reach of the common man. It has been confirmed according to [6] that more than 50million Nigeria has access to mobile phone but only less than $5 \%$ of these people are able to access intenet that they could use as education resource. There are evidences that students from Lower socio-economic who have low exposure and experience in ICT would not be enthusiastic in elearning, this will ultimately affect his/her performance in school. The proportion of students from lower socioeconomic backgrounds, who cannot currently afford a computer for use at home or internet access while they are studying is unknown. One might also speculate that lower socio-economic background students may, for financial reasons, have slower take-up of each new device or technology that comes onto the market which offers internet access. Access to e-learning in a variety of ways and from a variety of devices may therefore continue to be unequally distributed on the basis of one's economic or social social staus.

\section{Challenges of E-Learning Education to Learners}

Learners are exploring various methods of making effective learning possible. The emergence of e-learning has given wide opportunities for learners to engage in continuing and corporate education. This new trend has changed the roles of the teachers to more of facilitators as learners now learn on their own, collaborate and network easily for effective learning. Human interaction and collaboration are obvious advantages the face- to-face learning process has over the elearning process as interaction on the web is not physical and other features of human communication that enhance learning are absent. There are some unique contents that cannot be well handled through ICT, thus still making classroom training irreplaceable. Certain content because of its nature, relative value, or importance, is not suitable for technology-based delivery. Learning itself has its "edutainment value" of live experience and practical interactivity with a physical teacher. Some people are simply aversive to change; leaving their comfort zone is a great difficulty therefore to them, e-learning is not the most efficient learning method due to their traditional fixation. E-learning could be a good experience but the classroom has the unique features of providing guidance and motivation for students. E-Learning may require more dedication and discipline which most students' lack therefore teachers should guide students on what to do and how to do it, the school environment is capable of providing the needed support the learners need. Despite these challenges, e-Learning remains a veritable way to overcome time and place as barriers for the delivery of content and value added education services. The existing shortcomings of E-Learning pose great challenges to educators who must work to develop improved pedagogic models and techniques for e-learning education.

\section{Statement of the Problem}

There exists a lot of difference between the higher and lower social classes and these can be prominently observed when one takes a critical look at the students' performance in e-education setting. This study found out the existing gap between students of different socio-economic backgrounds in Nigeria and how these differences have affected their performance in e-learning education.

\section{Purpose of the Study}

This study is established to determine to what extent family socio-economic factors influence students' academic performance in e-learning education in Nigeria. The study also ascertained the types of social background and orientation students are exposed to, their relevance and adequacy.

\section{Hypotheses}

Ho1: There is no significant relationship between parental economic status and students' performance in e-learning, Ho2: There is no significant difference in students' parental educational background and their performance in e-learning.

\section{Methodology}

The study was carried out in Nigeria among 320 students of National Open University of Nigeria (NOUN). The major instruments used in collecting data for the study were the selfdeveloped instruments tagged socio-economic and e-learning performance rating scale of the students. The data collected were analyzed using ANOVA at (0.05 alphal level)

\section{Data Analysis A}

\section{Hypothesis 1}

Ho1: There is no significant relationship between parental economic status and students’ performance in e-learning.

Ha1: There is a significant relationship between parental economic status and students' performance in e-learning.

Significance level $(\alpha)=0.05$.

Decision: Accept Ho when $\mathrm{p}>0.05$

Reject Ho when $\mathrm{p}<0.05$

Table 1.0: Analysis of Variance of effect of parental economic status on students' Performance in e-learning.

\begin{tabular}{|c|c|c|c|c|c|}
\hline Source of variation & SS & df & MS & F-value & P-value \\
\hline Between groups & 55836.25 & 2 & 27918.12 & \multirow{3}{*}{169.37} & \multirow{3}{*}{$0.000 * *$} \\
\hline Within Groups & 37417.50 & 227 & \multirow{2}{*}{164.83} & & \\
\hline Total & 93253.75 & 229 & & & \\
\hline
\end{tabular}

** Significant at 0.01 
The results of analysis of variance (ANOVA) of effect of parental status on students' performance in e - learning are as shown in Table 1.0. The analysis showed that the parental economic status of students significantly affects their performance in e-learning $\left(\mathrm{F}_{2}, 227=169.37, \mathrm{p}<0.005\right)$

Table 2.0:_Post hoc analysis of effect of parental economic status on students' performance in e-learning.

\begin{tabular}{|c|c|}
\hline Parental economic status & $\begin{array}{c}\text { Performance of students in e-learning } \\
\text { (Mean } \pm \text { S.D) }\end{array}$ \\
\hline High & $45.82 \pm 4.33^{\mathrm{a}}$ \\
\hline Middle & $35.74 \pm 6.14^{\mathrm{b}}$ \\
\hline Low & $32.12 \pm 6.60^{\mathrm{b}}$ \\
\hline
\end{tabular}

Means followed by the same letter(s) in a column are not significantly

different from each other according to Duncan Multiple Range Test $(\mathrm{p}<0.05)$

Table 2.0 shows the post hoc analysis of the performance of students' in e -learning and their parental economic status. The analysis indicated that the scores of students in e-learning whose parents are of high economic status are significantly higher than students whose parents are of middle and low economic status. The e-learning scores of students whose parents are of middle and low economic status are not significantly different from each other.

Decision: Reject Ho and accept Ha.

\section{Hypothesis 2}

Ho 2: There is no significant difference in students' parental educational background and their performance in elearning.

Ha2:There is a significant difference in students' parental educational background and their performance in e-learning. Significance level $(\alpha)=0.05$.

Decision: Accept Ho when $\mathrm{p}>0.05$

Reject Ho when $\mathrm{p}<0.05$

Table 3.0: Analysis of Variance of effect of parental educational status on students' Performance in e-learning.

\begin{tabular}{|c|c|c|c|c|c|}
\hline Source of variation & SS & df & MS & F-value & P-value \\
\hline Between groups & 68294.47 & 3 & 22764.82 & & \\
\hline Within Groups & 29675.61 & 226 & \multirow{2}{*}{131.31} & & $0.000^{* *}$ \\
\hline Total & 97970.08 & 229 & & & \\
\hline
\end{tabular}

** Significant at 0.01

Table 3.0 shows the effect of parental educational status on students' performance in e-learning. The analysis indicated parental educational status significantly influenced students' performance in e-learning $\left(\mathrm{F}_{2}, 226=173.36, \mathrm{p}<0.005\right)$
Table 4.0:_Post hoc analysis of effect of parental educational status on students' performance in e-learning.

\begin{tabular}{|c|c|}
\hline Parental educational status & $\begin{array}{c}\text { Performance of students in e-learning } \\
(\text { Mean } \pm \text { S.D) }\end{array}$ \\
\hline No formal education & $25.32 \pm 2.19^{\mathrm{a}}$ \\
\hline Primary & $28.67 \pm 3.96^{\mathrm{b}}$ \\
\hline Secondary Tertiary & $36.81 \pm 5.40^{\mathrm{b}} 42.05 \pm 5.93^{\mathrm{c}}$ \\
\hline $\begin{array}{c}\text { Means followed by the same letter(s) in a column are not significantly } \\
\text { different from each other according to Duncan Multiple Range Test }(\mathrm{p}<0.05)\end{array}$ \\
\hline
\end{tabular}

Table 4.0 shows post hoc analysis of the performance of students' in e-learning and their parental educational status. The analysis indicated a significant difference in e-learning scores of students of different parental background. While there was no difference between the scores of students from primary and secondary parental educational background, these were significantly different from those whose parents did not have formal education. The scores of students whose parents had tertiary educational status were significantly different from those whose parents had no formal education, primary education and secondary education.

Decision: Reject Ho and accept Ha.

\section{Discussion}

From the findings above, parental economic status significantly affects the performance of students in e-learning education. This according to [2] is attributable to the ability of the parents to provide basic technological devices at home for the pupils to use. According to [10], parents provide home for the head start of children and the material for learning, when a child is deprived of the essential needs he may be found to perform poorly in his/her schoolwork. The study however showed that the e-learning scores of students whose parents are of middle and low economic status are not significantly different from each other.

Parental income was identified in this study as a cogent factor which determines the success of students in e-learning education. Most parental income was found not to be sufficient to sustain the academic and personal social life of the students in school and electronic learning is now more dynamic and requires constant upgrading in order to meet up with what is required for the various tasks. Thus, a student, irrespective of age or sex that does not have parental financial support when it is needed may not be able to afford some basic e-learning needs, such a student will suffer emotional disturbance which may result in distraction and frustration thereby leading to poor academic performance.

It is obvious from this study that parental educational qualifications play a leading role in forming the students. The study indicated a significant difference in e-learning scores of different parental background. Parents with high educational qualification, will have good knowledge of the importance of education, they will appreciate e-learning education and be prepared to make sacrifices for their children. Education of the parents remains a platform on which the education of the children stands. Thus, poor educational background may affect 
good educational outcome. The peculiar situation of this study is as a result of the age and the maturity of the students who are independent of their parents.

\section{Recommendations}

It is hereby recommended that parents should consider themselves a critical factor in determining the performance of students in their academic. The roles of parents cannot be ignored as they provide stimulating environment for their children without which their achievement in school may be very poor. Government should provide basic infrastructures that will make e-learning easy for the people. In this age of information technology, government should evolve a plan that will make citizens not just computer literate but capable of using electronic media to carry out daily functions including learning, with this, government's efforts to provide education for those who desire and qualify for higher education would be accomplished. Government should evolve a policy that will make e-learning education available for students of all levels; this can be done by making computer education a compulsory subject for all students, through the acquired skills, students would be fully prepared for e-learning education.

\section{Conclusion}

E-learning education is an emerging trend in Nigeria, despite its global popularity, Nigeria is just exploring this new and very effective way of learning and it is expected that more attention to factors that promote this type of learning be considered. The findings of this research rightly conclude that socio-economic background affects e-learning students both positively and negatively.

\section{References}

[1] Arogundade, W. O, The Roles of Parents in the Making of the Child. Ruvic Communicatios imited, Ibadan, 2002.

[2] Fafunwa, A.B New Perspective in African Education. Macmillan Education Limited, London, 1980.

[3] Guardian Newspaper, Federal Government Approves More Universities. Guardian Newspaper, 23rd February 2012. pp 2.

[4] Morrish, B, An Introduction to the Sociology of Education, Croom Helm Ltd, London, 1972.

[5] Obembe, R.T, The Making of the Total Child, Segerit Publishers Ltd, 2012.

[6] Obuh, R.O,Computer Literacy: The Age Factor, Arim Publishers, Lagos, 2010.

[7] Oyekan, S.O, Foundations of Teacher Education, Ebun Ola Printers Ltd, Okitipupa, 2000.

[8] Seufart, S, Back,A. Hauster, M, E-Learning: Cochbook for Internetbased Learning, Smartbook, Zeurich, 2001.

[9] Sprinthall, Educational Psychology: A Developmental Approach. 2nd Ed. Addeson Wesley, New York, 1987.

[10] Washer, P, "Barrier to the Use of Web-Based Learning in Nurse Education”, Nurse Education Today,2001, Vol 21, No 6, PP 455-460. 